\title{
TOPOGRAPHY OF A DREAM, OR SOME FEATURES OF NONLINEAR NARRATIVE
}

\author{
Saulius KETURAKIS \\ Kaunas University of Technology, \\ Faculty of Social Sciences, Arts and Humanities, \\ Department of Philosophy and Psychology, \\ A. Mickevičiaus g. 37, 44244 Kaunas, Lithuania \\ E-mail: saulius.keturakis@ktu.It
}

Received 11 September 2015; accepted 20 October 2015

\begin{abstract}
The article deals with the turn of the poetry of linear narrative into three-dimensional shapes, while topography and other spatial disciplines becomes an important tool to understand the meaning of new hypertextual narrative. Relying on the metaphors of Ted Nelson, the creator of the concept of hypertext about the magical and oneiric nature of a nonlinear story, the article represents the relationships between the topography of the spiritual world of the British Romanticism, written media transformation to a three-dimensional spatial structure in Nelson's hypertext project and postmodern practices of cultural dismantling. The article concludes that the traditional writing about hypertext is often not able to cover part of its features; the attention is drawn to the nature of hybrid art/scientific analysis of the new, intermedial "writing".
\end{abstract}

Keywords: crash, dream, hypertext, literature, play, quivering, reading.

\section{Introduction}

Language in which we understand, and experience which we understand often does not match; it is sometimes said, that language lags behind "one generation" (Meyer 2001: 47). According to Gertrude Stein, the generals of the World War I used weapons of the 20th century while perceiving the War in the categories of the 19th century. This is the case of hypertext, as we usually interpret it in terms of literary theory and poetics (Walker 2005). We conceptualize hypertext as e-poetry, or cyber literature, consisting of Roland Barthes' lexis. However, in this way we try to bring hypertext closer to what we already know very well, what has the systems of definitions and concepts rather than disclose the novelty and otherness.

These definitions have resulted from lack of understanding. Someday hypertext will become a customary written media, even though it (still) seems (Bolter 2001: 64) to be the utmost change of writing environment throughout the history of a written media. Everything will be conveyed in the form of hypertext and we will feel no revolution any more; nonlinear culture will not be characterized primarily as an 
anti-book (Salusinszky 1986: 8). And maybe then terminology that highlights the peculiarities of hypertext, which distinguish it from the previous reflection and communication traditions, will be formed. Maybe then we will begin to write and understand differently (Salusinszky 1986: 10).

For hypertext in the vision of the term creator Nelson ${ }^{1}$ had to be something quite different ${ }^{2}$. Yes, he saw the links of hypertextuality genealogy with literature ("literature is a system of interconnected writings" (Nelson 1981: 35)), but at the same time hypertext is something more to him, because linear written media is already in the past. "Writings in principle remain continuously available - both as recently quoted, and in their original inviolable incarnations" (Nelson 1981: 43), still, a step forward is needed; we need a new matrix, a new representation technology, new media, which has to be corrected, as if it were an outlier of literature as a technological algorithm, as stylistically described by Nelson's term "literature is debugged" (Nelson 1981: 3).

In this way, hypertext emerges as a prolongation of a written media, while simultaneously - in a vision created - something as if revolutionary and avant-garde in terms of art, something more perfect and advanced, something that allows thinking and expressing the ideas otherwise. And it becomes impossible to speak about this sense of otherness using barely adjusted concepts of classic literary theory and poetics.

The aim of this article is to overview the discourses which have become a source for describing hypertext and hypertextuality on the basis of the concepts, parallel to the traditional analytical perspective, in the hope that it will help to expose the otherness of the media, invented by Nelson.

\section{Magic and dream}

Magic and a dream are one of the first epithets, used by Nelson to describe hypertext. He refers to hypertext as "a magic place of literary memory" (Nelson 1981: 30), and a dream appears in the title of one of his books about hypertext Dream Machines. The most important dream-like feature of hypertext for Nelson is associated with imaginary action space, created by cinema, where imagination constantly reworks the relations between separate narrative elements and replaces the tack of the narrative into a network of ties, based on associations (Nelson 1987: 36). However, Nelson still considers cinema, even though it is a mass art, to be the media, too dependent on "the creeping evil of professionalism" (Nelson 1987: 38). Everything changes only after the sanctified - the director, cameramen or actors - convert a cinema screen into a computer monitor. Nelson interprets the latter as a radically democratized form of cinema media, affordable as naturally as food (Nelson 1987: 303). It is in the com-

\footnotetext{
${ }^{1}$ For a certain intellectual autobiography of this avant-garde thinker see Home Page of Ted Nelson (2001).

2 The most important Nelson's ideas, related to hypertext and hypertextuality, are described in his two books: Literary Machines (Nelson 1981) and Computer Lib/Dream Machines (Nelson 1987). The article will not analyze the history of hypertext as technology; it has already been analyzed in a number of studies. For one of the many databases see Blake (1997).
} 
puter space where a dream in the vision of Nelson's hypertext becomes a new format of information; there are no longer clear boundaries between different information forms - written texts and photographic images or the radio and cinema. And a dream is not anymore psychoanalytical means of reproduction of repressed information by symbols; it is a practice to find links between different information splits (States 1997: 3), and to overstep the set boundaries. Criticizing Western education system Nelson points out that training takes place only within the framework of certain disciplines (Nelson 1987: 67). Namely, oneiric nature of hypertextuality, in his view, would help teach treat information in another way, characteristic to children who have not passed into the levelling education system - there are no impassable boundaries, there are no connections impossible.

As Nelson states it, hypertext is not possible only on computer, but the latter is best suited to the requirements of the reconstruction of disassembled written line into a performative information network. In rather a poetic way than by argument, computer is announced to be beyond the order of a written media, because it is a magical space even without any content (Nelson 1987: 99). And speaking of space, certain geography is required to be able to orientate in it $^{3}$. In this way, Nelson names his hypothetical project of hypertext, implemented in a computer space, by a toponym Xanadu, borrowed from the British Romanticism.

The toponym Xanadu first appeared in Marco Polo's travel notes, but mostly it was popularized by one of the most famous British romantics Samuel Taylor Coleridge. He described the Chinese Emperor Kublai Khan's (1260-1294) summer residence Xanadu in his poem "Kubla Khan: Or, A Vision in a Dream: A Fragment" (created in 1798), which was written under an opium inspired vision. Images, inspired by an opium dream, create a place, which in a poetic text gets a form of ideal human spiritual topography. Its key feature - a miracle, leading to the fact that there is nothing impossible everything is linked to everything by a special phonetic instrumentation in the poem, and there is no linear sequence left. Moreover, everything what is happening is experienced only as pleasure (Kermode 2004: 26). Nelson chooses this geographical allegory for his hypertext project ${ }^{4}$ and turns this allegory into a symbol of metamedia, which in turn will have to become a structure of knowledge of the future world. An ordinary space-time is not likely to operate there, paradoxically the time of the reader and the writer has to coincide (Johnson-Eilola 1993: 383), be parallel and overlapping. In hypertext, human knowledge has to be "a combination of constantly intersecting all fields of knowledge" (Johnson-Eilola 1993: 385). However, parallelism and intersection, violating linear time, do not eliminate the possibility of history in hypertext, only here it acquires a very unusual shape. For Nelson, knowledge is the structures of idea intersections (Nelson 1987: 54), the changes of which in time

\footnotetext{
${ }^{3}$ Comp. Jay David Bolter's idea that Jacques Derrida's Glas is written in a topographical way; positioning on a page is more important than maintaining a consistent line there (Bolter 2001: 115).

${ }^{4}$ Nelson was very fond of the director Orson Welles' works. In Citizen Kane (created in 1941), Welles names the dwelling place of the main character Xanadu.
} 
compose historical content of hypertext epoch. Hypertextual Xanadu had to be space of words, where information on connection of these words with other words in the past is preserved. Such a conception of history requires a new paradigm of memory. However, Nelson cannot find it in a two-dimensional paper, as it can be found only while reading on a computer monitor. For both manuscript and printing do not have memory, they basically can only show the final version of information, and a combination of a computer monitor and electronic memory can overcome the linear time perspective and represent historical sequence, as a visible effect of the present moment, when the past has not been lost yet and is being constantly experienced. In the linearity, the present tense inevitably and continuously pushes the past form the field of direct experience. In Nelson's hypertext, both perspectives of time become parallel and not interchangeable by one another.

Such concept of time is similar to the one expressed in the saying of the hippie era (the period when hypertext project occurred): "The Child is father of the Man"

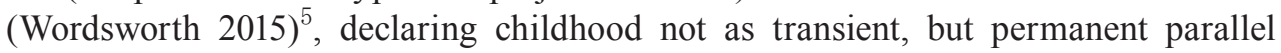
source of human existence.

\section{Author's/reader's quivering}

The most important structural element of hypertext is a hyperlink that joins various conceptual elements into a network. According to media theorist John M. Slatin, a hyperlink is a kind of traditional simulacrum of a linear pattern sequence (Slatin 1990: 880). A hyperlink itself has no semantics, as neither a sequence does; it only integrates information fragments. A hyperlink is a kind of silence zone, reminiscent of the gap between words or visual emptiness between the frames in a film (Björling 2011: 81), but spacing between words in a traditional written text is almost imperceptible, unless it is specifically increased and the film break between individual frames in general remains more notional than reflected (Björling 2011: 92). On the contrary, silence of a hyperlink in hypertext has become the most prominent and most significant of its elements. Such an abundance of a partially desemantised space (as only one element of a hyperlink is visible, another is only a hint) in hypertext is shocking to the reader, and forces him to get lost in any reflective try to orient himself in a simulation of the sequence of information flow (Landow 1992: 10). Unexpectedly, a trick is played on a hypertext reader, as instead of the promised ideal source of information he gets something more like a sheet of white paper, which he has to fill in. The English writer Laurence Sterne has prepared the Western reader for the trick in his novel The Life and Opinions of Tristram Shandy, Gentleman (1761-1767). According to the writer, the reader has to be provoked something to imagine. Through his main character Tristram the writer declares that writing is a dialogue, if to make a proper use of it. Moreover, the reader's point of view is as important to a piece of writing as the author's (Fluchère 1965: 273).

\footnotetext{
${ }^{5}$ A quatation from William Wordsworth's poem My Heart Leaps Up.
} 
Can it be said that hypertext reader turns into a joint author or even an actual author? Most of the works maintain this idea. However, making such conclusions overlooks an essential feature of hypertext, highlighted in Nelson's characteristics of hypertext, i.e. parallelism, and not displacement. We would benefit from Barthes' concept of amphiboly, found in his late works, describing the ambiguity of the word, which does not result from the lexicon, but due to the success of the discourse layout. Under favourable layout the same word in the same phrase means two different things, which manifest one through the other while reading. There appears a kind of semantic non-focus, quivering, or, according to the Barthes, amphiboly. The most important thing is not the notional polyphony, but the duality of the meaning (Barthes 2010: 72-73), a certain change, reminiscent of cinematographic Lev Kuleshov's montage experiments (Mancini 2005: 112).

If to go back to hypertext hyperlinks, involving the reader in a joint work of imagination together with the author, more accurate characteristics of hypertext reading would refer to the author's/reader's quivering, forcing the reader to constantly alternate the prospects of self-perception and the practices of information use.

The author's/reader's quivering is sometimes interpreted through different conceptions of textuality. It is said that a traditional linear text is a metonymy, and its end - a metaphor, as the text leads through the narrative related by logical links to understanding of the metaphorical text as a whole (Lunenfeld 2000: 41). Hypertext proposes an alternative, inverted reading scheme: a text marked in hyperlinks is a kind of a map of a certain scale, the metaphor of the whole text, and the reader then has to become a co-author and create a metonymy, a narrative of elements connected by logical connections. In both cases, it comes to the same narrative; only in case of a linear text, the reader understands that he has reached the end of the text, while reading hypertext the reader as if starts from the point of understanding and dismantles it into related elements (rejecting the metaphorical illusion of the whole).

\section{Hypertext: is this serious?}

The publishing house Eastgate, one of today's largest hypertext research centres, declares on its website that its field of interest is only "serious hypertext" (Eastgate.com 2010). The predicate of seriousness in the profile of the publishing house has not appeared by accident, it is concerned with the continuing debate about the possibilities of hypertext to continue the classic distinction of low and high culture, or, to be more precise, whether hypertext can maintain the classic forms of high culture, literary or scientific $^{6}$.

In considering this issue, hypertext studies have pointed out that one of the main hypertext reader's experiences is ergodicity, or notional trajectories of hypertext path dependent on his own initiative (Aarseth 1997: 75). This makes it possible to speak of

\footnotetext{
${ }^{6}$ One of the most substantial examples of this discussion is Stuart Moulthrop's article "The Shadow of an Informand: A Rhetorical Experiment in Hypertext" (Moulthrop 2015).
} 
certain mimicry of hypertext, adaptation to the uniqueness of the reader's intent. In other words, hypertext itself can belong neither to high, nor to low culture, because only the reader can make it in one way or another.

However, despite the performativity of hypertext media and total dependence on the user, the research has not refused hope to find a criterion to define certain possibilities to turn hypertext into the forms of high or low culture. The possibility of such distinction has been formulated pointing out a distinction between transformations of the narrative, related to the loss of written textuality and the entrenchment of a visual narrative.

One of the most influential theorists of hypertext George Landow took the situation of a hypertext narrative in computer games to be a certain low culture of hypertext due to their excessive involvement in visual culture (Landow 1994: 49). In 2000, J. Yellowlees Douglas in her book The End of Books - Or Books without Ends wrote, while distinguishing between computer games and serious hypertext, that computer games have obeyed the trajectory of recreational adventure narrative since their early beginning (1952), and hypertext continued what the author called a petty avant-garde prose, mostly related to conceptual problems as well as various thought experiments (Douglas 2000: 38). Another hypertext researcher Phil Goetz affirms the same provision arguing that most hypertext readers perceived the transformation of textual adventure into visual adventure as the loss of elite hypertext genre (Goetz 1999). In his opinion, one of the first computer games Mystery House (created in 1980 according to Agatha Christie's detective story And Then There Were None (first edition in 1939) (2011) is the moment in Western culture, when a text adventure was radically changed into a visual one. According to the author, the visual scenarios of the computer game were much more banal than the original story, as a tense detective story was sacrificed in the name of a more spectacular visuality.

It seems that if hypertext wants to remain in the discourse of serious literary fiction, it just has to keep a written medium, and that will be the distinguishing feature of distancing itself from "not serious" visual entertainment. However, addressing the problem whether, say, philosophy is possible in non-linear media in general, the answer is not clear even today. Hypertext media was perfect for information maintenance and search, and hypertext proved to be a very viable medium for art fiction. However, this non-linear media seems to be difficult to apply to what we call an argument, its recording, transfer and integration into other systems of arguments. And if call it philosophy, hypertext would be the most improper medium for it.

Obviously, the essence of the latter discussion - whether nonlinear hypertext and philosophy are compatible - is related to integral interface of an argument and philosophy, and the nature of an argument itself. Traditionally, an argument is linear. And if refusal of linearity in a novel is an inspiring revolution against, according to Georg Wilhelm Friedrich Hegel, middle-class epic (Coover 1992: 23-25), the transfer of the same activity to philosophy (breaking up an argument) is not so unambiguous.

Hypertext theorist David Kolb notes that the main argument against nonlinear philosophy writing is that philosophy requires an argument, and an argument is inevitably composed of an introduction, body and conclusions. Philosophy requires a line 
instead of a cloud of unlinked statements. A line of philosophical consideration cannot be dismantled; though, it was enthusiastically done with the traditional narrative. Therefore, philosophy must inevitably deal respectfully with a linear structure of an argument (Kolb 1993). Kolb, speaking about the suitability of philosophy to hypertext, notes that the nonlinearity eliminates one of the most important elements of a philosophical text - a consideration sequence. The question is - can nonlinear hypertext, which has no conceptual "path" provided by the author and which, as mentioned above, mimicrically always adapts to the reader, be used as a medium of thinking, capturing insights and sharing them?

Kolb notes that the history of philosophy teaches systematics and circuits of arguments; if we eliminated them, philosophy would turn into a chaotic conceptual acupuncture of rhetorical figures. On the other hand, the form of the genre of a postmodern philosophical text, or philosophizing in general, has become much more diverse than in classical times; an anthology or an essay has basically turned into its basic forms (Kolb 1993). So, one would expect nonlinearity of hypertext to be harmonized with the principle of systematic philosophizing someday in some way.

Kolb sees certain symptoms of such compatibility in the evolving concepts of what can be defined as a path to understanding. This can be a stimulation of different consciousness or even bodily states, provocation of certain moods, enthusiasm, frustration or fatigue (Kolb 1993). However, according to Kolb, hypertext can influence the user faced with nonlinear medium through its accumulated words and other media, as well as the user's thinking trajectories, bring him to a certain understanding; but the user cannot justify his path critically after reaching the goal.

Media theorist Charles Ess does not see anything wrong in the loss of this criticism. As he states it, "in a postmodern theory, the line of an argument was adopted as heritage of written culture, which must be abandoned as soon as possible; as a certain type of rhetoric or narrative, associated with a particular historical epoch" (Ess 1996). According to Ess, the way of postmodern intellectual activity and its objectives should be formulated in a completely different way - it should be a never-ending development of ideas without concern to convince or prove anything.

If to perceive philosophy as a labyrinth of continuous development of ideas without seeking for any quod erat demonstrandum, nonlinear hypertext becomes a very favourable media.

\section{An accident with tradition}

Hypertext has become a major problem to the forms of "high" culture tradition. Robert Coover in his famous essay on the end of a book era has spoken about the interaction of hypertext and traditional written language as a war, in which the writer will be worn out by the constant need to fill in a boundless digital "paper" fields (Coover 1992: 24). He extended the idea of Michiko Kakutani by saying that hypertext finishes the era of "responsible" writing (Kakutani 1997: 40-41). These and many similar statements make it clear that the feeling that hypertext represents a serious risk for the whole discourse of critical thought is very intense. 
First of all, one can see this from its endlessness and elevation of the process above any finite results. In his book Disappearing through the Skylight, William Shakespeare researcher O. B. Hardison, Jr. tried to imagine hypertextual edition of Shakespeare's "The Storm", which in addition to the main text would publish related Shakespeare's notes, available resources, academic research and all theatrical performances. The question is what would happen to "The Storm" if to put it in such a hypertextual form? It would turn into a strange collage of facts, text fragments and interpretations. According to O. B. Hardison, Jr., if we read "The Storm" in such a "way", Shakespeare's text would disappear (O.B. Hardison, Jr. 1990: 48). In this kind of interpretation, hypertext is a killer of classic cultural tradition, and the major crime "tool" is the fragmentarity of hypertext and the rejection of responsibility for the end.

"The end is in the beginning", said Samuel Beckett through the lips of one of his characters in the play Endgame (2009). Only the end allows escaping from the absurd of endless repetition of questions and answers, it allows going back to the beginning and understanding the narrative as a whole. It is the end in this play, which is interpreted as creating what is called a meaningful reality, which creates connections and communication between the individual fragments (Adorno 1961: 261). The lack of the end in hypertext excludes the possibility of the creation of such a meaningful reality; everything remains just as endless wandering in the space in the mazes of somehow linked information fragments.

Terry Winograd and Fernando Flores tried to describe the situation of today's hypertext reader on the basis of such allegory: a big dog pops out in front of a car driving at high speed in a fog. The behaviour of the driver does depend neither on his rational thinking, nor on different concepts. The driver's action will be spontaneous and automatic, depending more on reflexes than on reflection (Winograd, Flores 1987: 41). This is automatism, which is noticeable in the hypertext readers' practice. We live in the beginning of the era of rapid information and here we no longer have any opportunity to stop and reflect; we are in a sort of permanent "emergency" reading experience. Strangely enough, in an early hypertext, namely the motif of an accident and understanding, caused by a catastrophe, is very common; as well as the motif of speed, which distracts from intended lines. In Michael Joyce's Afternoon, a Story (first edition in 1987 (2015)), the first hypertextual fiction, the story starts to evolve in different trajectories when the main character gets scared that he can find the bodies of his son and ex-wife in the wrecked car. Douglas' work "I Have Said Nothing" (1994) also poses a seemingly purely technical question: what would happen to you if a Chevrolet hit you at a speed of $150 \mathrm{~km} / \mathrm{h}$ ? The story reminds of an analytical scientific discourse, calmly describing the panorama of injuries and wrecks.

Does this trope of an accident mean anything? The crash and its effect is a shock, one of the possible traumas pointed out by Douglas. This effect is caused by hypertext; a trauma, allegorically speaking about the spiritual state while exposing the traumas of the body/text or "traumas". According to Michael R. Heim, "lexis", linked with other lexis in hypertext, shows the disintegration of the boundaries between the different texts. When a membrane of a cell collapses, it dies. The text itself does not die, just our expectations concerning it radically change". A hyperlink is the materi- 
alization of text "collision", consequently, a deep shock effect seeing after-crash text fragments and body parts of former passengers - authors and readers (Heim 1999: 142).

Is it possible to avoid the accident? Let us say, simply by turning off from a hyperlink coming at a high speed? It is because of the traumatic nature of hypertext that we talk about the withdrawal from the area of violence, the traditional linear text, the author and the reader's rescue.

However, such a withdrawal does not help to understand the hypertext media. It seems that if we do not take a step back, but move forward the "deep shock", we can learn something more about the collision itself. It is basically a conception of a postmodern text, in which each "node", from which the understanding consciousness "breaks" into infinite contexts, is linked to a certain network. These nodes (or hyperlinks) are certain "accidents", which make to look at well-known things in a new way.

Hypertext is a collision of texts, a bang and a dispersal of parts on the "highway" of postmodern culture. It is a big epic about an accident and confusion.

\section{Conclusions}

When writing a linear text about nonlinear hypertext, it is impossible to avoid the feeling that the gap between the two media is too large for reliable communication. After the tour in the anthologies of hypertextual works (the one made up at the Massachusetts Institute of Technology seems to be the most representative (Electronic Literature Organization 2006)), one should pay attention to the verbs research, explore, introduce, analyse, and the like, which occur very often in the works of annotations and which are more characteristic of science, not art discourse. It is quite likely that this is a more appropriate way to talk about hypertextuality, and specific reading and viewing practices, created by it, as well as the effects of various media interaction, than the pure written media. Synthesization of experience (art) and critical reflection (science) into a single genre demands a completely different literacy (the one of the new media), the ability to manipulate the reader's states alternating a wide range of critical and anti-critical prospects, showing and revealing (classical tradition) or disguising and concealing (hypertext tradition) the ways in which the reader finds himself in one or another "spot" of his consciousness.

\section{References}

Aarseth, E. J. 1997. Cybertext: Perspectives on Ergodic Literature. New York: Johns Hopkins University Press.

Adorno, Th. W. 1961. Versuch, das "Endspiel” zu verstehen, in Noten zur Literatur. Frankfurt am Main: Suhrkamp Verlag, 188-236.

Barthes, R. 2010. Roland Barthes by Roland Barthes. London: Hill and Wang.

Beckett, S. 2009. Endgame. London: Faber and Faber.

Björling, F. 2011. Stillness and Silence in Alexander Sokurov's Films: An Affinity with Japan, in Toyota, J.; Hallonsten, P.; Shchepetunina, M. (Eds.). Sense of Emptiness: An Interdisciplinary Approach. London: Cambridge Scholars Publishing, 80-93. 
Blake, W. 1997. Select Bibliography on Hypertext, Its Theory, History, and Practice, and on Hypertext Research Sites [online], [cited 12 June 2015]. Available from Internet: http://www.unc. edu/ jsviscom/372/bib.html

Bolter, J. D. 2001. Writing Space: Computers, Hypertext, and the Remediation of Print. Mahwah, NJ: Lawrence Erlbaum.

Christie, A. 2011. And Then There Were None. London: Harper.

Coover, R. 1992. The End of Books, The York Times on the Web [online], [cited 10 June 2015]. Available from Internet: https://www.nytimes.com/books/98/09/27/specials/coover-end.html

Douglas, J. Y. 1994. I Have Said Nothing [online], [cited 12 June 2015]. Available from Internet: http://www.wwnorton.com/college/english/pmaf/hypertext/ihsn/i_have_said_nothing.html

Douglas, J. Y. 2000. The End of Books - Or Books without End?. New York: The University of Michigan Press.

Eastgate.com. 2010 [online], [cited 26 June 2015]. Available from Internet: http://www.eastgate.com/

Electronic Literature Organization. 2006. Electronic Literature Collection [online], [cited 9 June 2015]. Available from Internet: http://collection.eliterature.org/

Ess, Ch. 1996. Modernity and Postmodernism in "Hypertext Notes": A Call for Theoretical Consistency and Completeness, EJournal 6(3) [online], [cited 10 June 2015]. Available from Internet: http://www.ucalgary.ca/ejournal/archive/v6n3/ess/ess.html

Fluchère, H. 1965. Laurence Sterne: From Tristram to Yorick. An Interpretation of Tristram Shandy. Oxford: Oxford University Press.

Goetz, Ph. 1999. Interactive Fiction and Computers [online], [cited 10 June 2015]. Available from Internet: http://mud.co.uk/richard/ifan194.htm

Heim, M. 1999. Electric Language: A Philosophical Study of Word Processing. New York: Yale University Press.

Home Page of Ted Nelson. 2001 [online], [cited 1 June 2015]. Available from Internet: http:// xanadu.com.au/ted/

Johnson-Eilola, J. 1993. Control and the Cyborg: Writing and Beeing Written in Hypertext, Journal of Advanced Composition 13(2): 381-399.

Joyce, M. 2015. Afternoon, A Story [online], [cited 30 June 2015]. Available from Internet: http:// www.eastgate.com/catalog/Afternoon.html

Kakutani, M. 1997. Culture Zone: Never-Ending Saga, The New York Times Magazine [online], [cited 1 June 2015]. Available from Internet: http://www.nytimes.com/1997/09/28/magazine/culture-zone-never-ending-saga.html

Kermode, F. 2004. Pleasure and Change: The Aesthetics of Canon. Alter, R. (Ed.). Oxford: Oxford University Press.

Kolb, D. 1993. Socrates in the Labyrinth: Hypertext, Argument, Philosophy. Watertown, MA: Eastgate Systems Inc.

Landow, G. P. (Ed.). 1994. Hyper/Text/Theory. Baltimore/London: John Hopkins University Press.

Landow, G. P. 1992. Hypertext: The Convergence of Contemporary Critical Theory and Technology. Baltimore: Johns Hopkins University Press.

Lunenfeld, P. 2000. The Digital Dialectic: New Essays on New Media. Cambridge: MIT Press. 
Mancini, C. 2005. Cinematic Hypertext: Investigating a New Paradigm. Series: Frontiers in Artificial Intelligence and Applications. Vol. 122. Amsterdam: IOS Press.

Meyer, S. 2001. Irresistible Dictation: Gertrude Stein and the Correlations of Writing and Science. Stanford: Stanford University Press.

Moulthrop, S. 2015. The Shadow of an Informand: A Rhetorical Experiment in Hypertext [online], [cited 10 June 2015]. Available from Internet: http://www.pd.org/Perforations/perf3/shadow_of_info.html

Nelson, T. 1987. Computer Lib/Dream Machines. Stroud: Tempus Books.

Nelson, Th. H. 1981. Literary Machines. Sausalito: Mindfull Press.

O.B. Hardison, Jr. 1990. Disappearing through the Skylight: Culture and Technology in the Twentieth Century. London: Penguin Books.

Salusinszky, I. 1986. Jacques Derrida on the University, Southern Review 19: 3-12.

Slatin, J. M. 1990. Reading Hypertext: Order and Coherence in a New Medium, College English 52(8): 870-883. http://dx.doi.org/10.2307/377389

States, B. O. 1997. Seeing in the Dark: Reflections on Dreams and Dreaming. New Haven: Yale University Press.

Walker, J. 2005. Feral Hypertext: When Hypertext Literature Escapes Control [online], [cited 12 June 2015]. Available from Internet: http://jilltxt.net/txt/FeralHypertext.pdf

Winograd, T.; Flores, F. 1987. Understanding Computers and Cognition: A New Foundation for Design. London: Addison-Wesley Professional.

Wordswoth, W. 2015. My Heart Leaps Up [online], [cited 3 July 2015]. Available from Internet: https://www.poets.org/poetsorg/poem/my-heart-leaps.

\title{
SAPNO TOPOGRAFIJA, ARBA APIE KAI KURIUOS NELINIJINIO NARATYVO YPATUMUS
}

\author{
Saulius KETURAKIS
}

\section{Santrauka}

Šiame straipsnyje aptariamos linijinio naratyvo transformacijos i i ivairius erdvinius pavidalus, kai topografija ir kitos erdvès disciplinos tampa esminėmis priemonėmis, padedančiomis suprasti hipertekstualaus naratyvo prasmę. Remiantis Tedo Nelsono, hiperteksto koncepcijos kūrèjo, metafora apie nelinijinio naratyvo magiškają ir sapnų prigimti bei jos sąsajas su britiškojo romantizmo dvasinio gyvenimo kaip erdvinio diskurso ideja, straipsnyje parodomos linijinès rašto medijos transformacijos i trimatę erdvę Nelsono hiperteksto projekte. Tuo pat metu, baigiant analizę, daroma išvada, kad tradicinè linijinè rašto medija kaip analitinè priemonė neapima visų hipertekstualaus pasakojimo ypatumų. Šiam tikslui kur kas parankesnè yra hibridinè meninè / mokslinė analizė, pasireiškianti naujojo, intermedialaus „rašymo“ srityje.

Reikšminiai žodžiai: avarija, sapnas, hipertekstas, literatūra, žaidimas, mirguliavimas, skaitymas. 